\title{
Anti-Inflammatory Activity of Marine Sponge Aaptos sp. to the Plasma Interleukin-1ß Level in Wistar Male Rats
}

\author{
Adryan Fristiohady ${ }^{1}$,Wahyuni Wahyuni ${ }^{1}$, Wa OIL. Kalimin ${ }^{2}$, La OMJ. Purnama ${ }^{1}$, \\ Saripuddin Saripuddin ${ }^{1}$, Idin Sahidin ${ }^{1}$ \\ ${ }^{1}$ Faculty of Pharmacy, Halu Oleo University, Kendari, Southeast Sulawesi, Indonesia \\ ${ }^{2}$ Faculty of Medicine, Halu Oleo University, Kendari, Southeast Sulawesi, Indonesia
}

\begin{abstract}
Inflammation is the response of the body to injury and infection characterized by swelling, heat, pain, and redness. This study aimed to investigate the anti-inflammatory effect of Aaptos $s p$. ethanolic extract to plasma interleukin (IL)-1 $\beta$ level of Wistar male rats. Aaptos sp. was macerated with $96 \%$ ethanol for $3 \times 24$ hours. Inflammation was induced with administration of $1 \%$ carrageenan intraplantarly. Animals were divided into 5 treatment groups, i.e., positive control (diclofenac sodium 3598 ppm); Aaptos sp extract 50 ppm; Aaptos sp extract 100 ppm Aaptos sp extract 200 ppm; and negative control (0.5\% Na CMC). After 1 hour, blood was collected and assayed using enzyme-linked immunosorbent assay (ELISA) kit. The results showed that plasma IL- $1 \beta$ levels of animals were decreased by Aaptos $s p$ ethanolic extract. The administration of $50 \mathrm{ppm}$ of extract showed no significant difference $(\mathrm{p}>0.05)$ in IL-1 $\beta$ level in first and second hour measurement, but indicated a statistically significant decrease after three hour $(\mathrm{p}<0.05)$. The administration of $100 \mathrm{ppm}$ of extract showed no significant difference $(\mathrm{p}>0.05)$ in every hour. Significant reduction was observed in the administration of $200 \mathrm{ppm}$ of extract, but the elevation of IL-1 $\beta$ levels was also observed at third hour measurement. In conclusion, ethanolic extract of Aaptos sp. had anti-inflammatory activity and its effective dose was $50 \mathrm{ppm}$.
\end{abstract}

Keywords: anti-inflammatory; ethanolic extract; Aaptos sp.

\section{Introduction}

Inflammation is the reaction of living tissue towards infection and injury, characterized by tumor, calor, dolor, and rubor. It comprises local and systemic response. Nevertheless, the consumption of anti-inflammatory drugs in the long-term might trigger potential side effect, such as increased risk of peptic ulcer, constipation, kidney problem, etc. ${ }^{1,2}$

Terrestrial and marine biodiversity of Indo nesia are abundant. These natural resources can be utilized in many aspects, including as traditional medicine. Around $31.4 \%$ of Indonesian people utilize traditional medicine to self medicate themselves. ${ }^{3}$ Marine sponge such as Aaptos sp. is empirically used to treat several diseases. Based on the previous study, Aaptos sp. has been reported to have antibacterial, anti-cancer, and anti-depressant activities. ${ }^{3}$ Aaptamine, an alkaloid from Aaptos $s p$., is predicted to be responsible for antiinflammatory activity because of its ability to

Corresponding author: Idin Sahidin. Faculty of Pharmacy, Halu Oleo University, Kendari, Southeast Sulawesi, Indonesia. Email: sahidin02@uho.ac.id

Received: 6 July 2019. Revised: 2 August 2019 Published: 30 August 2019. 
reduce cytokines such as IL-1 $\beta$ as a regulator for inflammatory response. ${ }^{4,5}$

There is limited information regarding antiinflammatory activity of Aaptos $s p$. ethanolic extract with regards to its activity towards IL-1 $\beta$ level in plasma. Thus, this study aimed to investigate the anti-inflammatory effect of Aaptos sp. ethanolic extract to plasma IL-1 $\beta$ level of Wistar male rats.

\section{Methods}

The conduct of this study was approved by Ethics Comitee of Halu Oleo Univeristy (No.2685/UN29.20/PPM/2018).

\section{Sample collection and extraction}

Aaptos sp. was collected from Bintang Samudra Marine Edu-Park, Soropia Sub District, Konawe, Southeast Sulawesi, Indonesia. Aaptos sp. was obtained by scuba diving and collected by hand at reef slope $\left(70^{\circ}\right), 10 \mathrm{~m}$ above sea level. Aaptos sp. was then sorted, washed and cleaned from impurities. Thereafter, the sponge sample was put in storage for further process. Aaptos sp. was put in a clear jar and macerated with $96 \%$ ethanol (1:2) for 3 days. The extract was stirred everyday. The crude extract was obtained by filtrating the solvent using filter paper (Whatmman $\left.{ }^{\circledR}\right)$. The crude extract was then concentrated using vacuum rotary evaporator at 50 ${ }^{0} \mathrm{C}$ and waterbath at $37{ }^{\circ} \mathrm{C}$.

\section{Anti-inflammatory assay}

Experimental animals used in this study were Wistar male rats (200-250 g). Animals were obtained from animal farm in Surabaya, Indonesia. Wistar male rats were acclimatized for 1 month. Wistar male rats were put in standard environmental $\left(22 \pm 2{ }^{\circ} \mathrm{C}\right)$ with free access to pellet chow and water ad libitum.

Wistar male rats $(\mathrm{n}=20)$ were divided into 5 groups $(n=4)$. At the day of the experiment,
$1 \%$ carrageenan was injected intraplantarly to induce inflammation. Subsequently, each group was given treatment orally; positive control (diclofenac sodium 3598 ppm); Aaptos $s p$ extract 50 ppm; Aaptos sp extract 100 ppm; Aaptos sp extract 200 ppm; and negative control ( $0.5 \% \mathrm{Na} \mathrm{CMC})$. Animals were left for 1 hour and blood was collected via tail vein at the first and second hours and cardiac puncture at the third hour post injection. Blood was collected and centrifugated (Thermo Scientific ${ }^{\mathrm{TM}}$ ) at $1000 \mathrm{rpm}$ for 15 minutes. It was examined using ELISA Kit (Elabscience ${ }^{\circledR}$ ) to measure the plasma IL-1 $\beta$ levels of animals. Data obtained from ELISA assay was then analyzed using SPSS with Saphiro-Wilk, continued by One Way ANOVA followed by post-hoc LSD test.

\section{Results and Discussion}

The results showed plasma IL-1 $\beta$ levels of animals were decreased by administration of Aaptos $s p$ ethanolic extract. Extract 50 ppm showed greater effect in decreasing plasma IL-1 $\beta$ level of Wistar male rats compared to the dose of $100 \mathrm{ppm}$ and $200 \mathrm{ppm}$ (Figure 1). The administration of $50 \mathrm{ppm}$ of extract showed no significant difference $(\mathrm{p}>0.05)$ in IL-1 $\beta$ level in first and second hour measurement compared to negative control group, but indicated a statistically significant decrease after three hour $(\mathrm{p}<0.05)$. The administration of $100 \mathrm{ppm}$ of extract showed no significant difference with negative control group $(p>0.05)$ in every hour. Significant reduction was observed in the administration of 200 ppm of extract, but the elevation of IL-1 $\beta$ levels was also observed at third hour measurement. (Figure 1). Nevertheless, compared to positive control group, the anti-inflammatory activity of Aaptos $s p$ was slightly lower. Effect of Aaptos sp. extract 50 and $100 \mathrm{ppm}$ had a significant difference $(\mathrm{p}<0.05)$ compared to psotive control group on 1st hour measurement (Table 1). 
Table 1. Anti-Inflammatory Activity of Aaptos sp

\begin{tabular}{lccc}
\hline \multicolumn{1}{c}{ Group } & \multicolumn{3}{c}{ P values } \\
\cline { 2 - 4 } & 1st Hour* & 2nd Hour** & 3rd Hour* \\
\hline C+ vs C- & 0.021 & 0.000 & 0.564 \\
C+ vs A50 & 0.021 & 0.292 & 0.021 \\
C+ vs A100 & 0.021 & 0.000 & 0.149 \\
C+ vs A200 & 0.386 & 0.473 & 0.564 \\
C- vs A50 & 0.149 & 0.000 & 0.021 \\
C- vs A100 & 0.021 & 0.000 & 0.564 \\
C- vs A200 & 1.000 & 0.000 & 0.386 \\
A50 vs A100 & 0.021 & 0.000 & 0.021 \\
A50 vs A200 & 1.000 & 0.088 & 0.021 \\
A100 vs A200 & 0.021 & 0.000 & 0.248 \\
*=Mann-Whitney Test; ${ }^{* *}=$ LSD test; $p<0.05=$ significant difference; $p>0.05=$ no significant difference
\end{tabular}

Il- $1 \beta$ is one of the pro-inflammatory cytokines that is primarily associated with innate immunity. It regulates the innate inflammation response. It also involved in cancer progression and affecting the growth and invasion of almost all types of tumor cells. ${ }^{6}$

One of the substances in Aaptos sp. that is responsible for its anti-infammatory properties is Aaptmine. The possible mechanism of
Aaptmine as anti-inflammatory agent toward IL-1 $\beta$ are: (1) aaptamine incorporates into IL-1 $\beta$ DNA chain with low affinity thus interrupts the protein arrangement; (2) at low-dose, it inhibits proteasome in degradation of IL- $1 \beta$ forming protein and at high-dose it induces pro-apoptosis; or (3) aaptamine inhibits IL$1 \beta$ signal which initiates metabolism of arachidonic acid (AA) in lipooxigenase (LOX) pathway. ${ }^{7-10}$

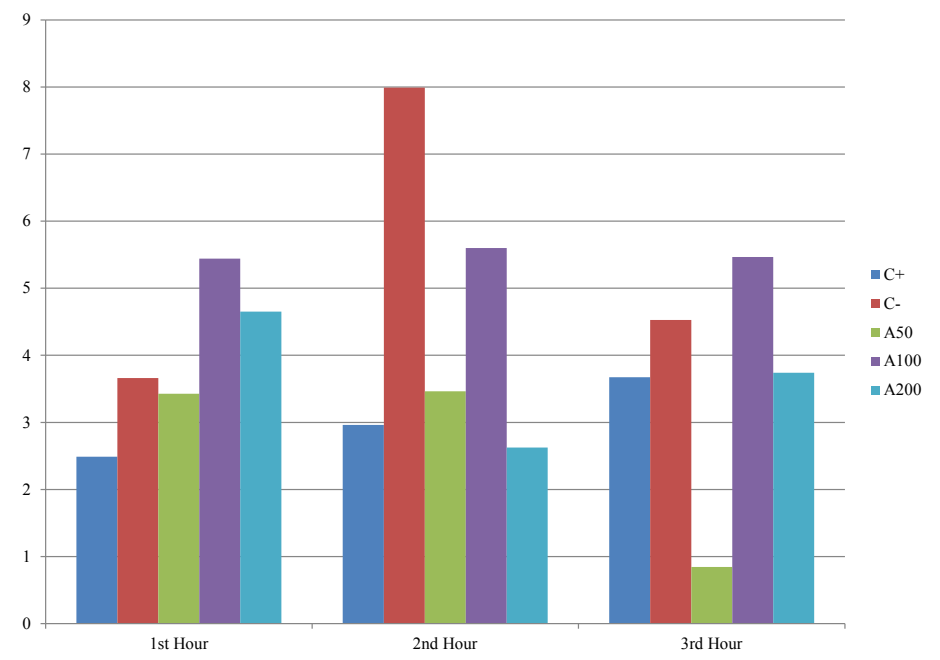

Figure 1. Mean Decrease of IL-1 $\beta$ in EachTreatment Group over Three Hours 
We found that the anti-inflammatory activity of Aaptos sp. depends on onset and concentration. At the dose of $50 \mathrm{ppm}$, the effect was observed during second and third hour measurement post injection. It even decreased IL-1 $\beta$ level significantly $(p<0.05)$ after three hours. The delayed effect was occurred since ethanolic extract might takes longer time to distribute into the inflammation site. ${ }^{8,9}$ The dose of 100 ppm showed no significant difference $(p>0.05)$ between the first, second, and third hour measurement. It was possibly due to equilibrium process between inhibition ability and toxicity. ${ }^{10,11}$ The dose of 200 ppm showed that optimal effect occurred at the second hour of measurement. However, it increased the IL-1 $\beta$ on third hour measurement. It was possibly due to the toxicity effect of a higher dose Aaptos sp. ethanolic extract. ${ }^{12,13}$

\section{Conclusion}

Ethanolic extract of Aaptos sp. had antiinflammatory activity and its effective dose was $50 \mathrm{ppm}$. Further study is needed for investigating the effect of ethanolic extract of Aaptos sp. by using different cytokines parameter.

\section{Acknowledgement}

The authors thank the Ministry of Research, Technology, and Higher Education of the Republic of Indonesia for their financial support.

\section{Funding}

This study was funded by Ministry of Research, Technology, and Higher Education of the Republic of Indonesia, in a research grant scheme: Penelitian Dasar Unggulan Perguruan Tinggi 2018.

\section{Conflict of Interests}

None declared

\section{References}

1. National Health Research. 2018. Jakarta: Ministry of Health, Republic of Indonesia.

2. Abdillah S, Zuraiha F, Syarmalina S. Evaluation of antibacterial activities of secondary metabolites produced by Aaptossuberiptoides associated bacteria. Journal of Pharmacy and Biological Sciences. 2014;9(6):34-38.

3. Ciaglia E, Malfitano AM, Laezza C. Immuno-modulatory and anti-inflammatory effects of dihydrogracilin a, a terpene derived from the marine sponge dendrilla membranosa. International Journal of Molecular Science. 2017;18(8):1643.

4. Dyshlovoy SA, Venz S, Shubina LK, et al. Activity of aaptamine and two derivatives, demethyloxyaaptamine And dsoaaptamine, in cisplatin-resistant germ cell cancer. Journal of Proteomics 2013;1:1-17.

5. Settrerrahmane S, Xu H. Tumor-related in interleukins: old validated targets for new anti-cancer drug development. Molecular Cancer. 2017;16:153-155.

6. Dyshlovoy SA, Fedorov SN, Shubina LK. Aaptamines from the marine sponge Aaptos sp. display anticancer activities in human cancer cell lines and modulate AP-1-, NF-кB-, and p53-dependent transcriptional activity in mouse JB6 Cl41 cells. Biomed Research International. 2014;2014:469309.

7. Dinarello CA. Overview of the IL-1 family in innate inflammation and acquired immunity. Immunology Review. 2018;281(1):8-27.

8. Dinarello CA. Interleukin-1 in the pathogenesis and treatment of inflammatory diseases. Blood. 2011;117(14):37203732.

9. Shaari K, Ling KC, Rashid ZM. Cytotoxic aaptamines from Malaysian Aaptos 
aaptos. Marine Drugs. 2009;7(1):1-8.

10. Kesarwani K, Gupta R, Mukerjee A. Bioavailability enhancers of herbal origin: An overview. Asian Pacific Journal of Tropical Biomedicine. 2013;3(4):253266.

11. Shubina LK, Makarieva TN, Dyshlovoy SA. Three new aaptamines from the marine sponge Aaptos sp. and their proapoptotic properties. Natural Product Communications. 2010;5(12):1881-1884.

12. Dyshlovoy SA, Naeth I, Venz S. Proteomic-based screening of protein targets of aaptamine, a marine alkaloid with antiproliferative activity. Annals of Oncology. 2012;23:32-34.

13. Pan MH, Chiou YS, Tsai ML, Ho CT. Anti-inflammatory activity of traditional Chinese medicinal herbs. Journal of Traditional and Complementary Medicine. 2011;1(1):8-24.

14. Oguntibeju OO. Medicinal plants with anti-inflammatory activities from selected countries and regions of Africa. Journal of Inflammation Research. 2018;11:307317. 